\title{
Toxoplasma gondii in Sheep and Goats from Central Iran
}

\author{
Mojtaba Bahreh ${ }^{1,2}$, Bahador Hajimohammadi ${ }^{1,3}$ and Gilda Eslami $i^{1,4^{*}}$ (D)
}

\begin{abstract}
Objective: Toxoplasmosis, caused by Toxoplasma gondii, infects humans by consuming infected raw or undercooked meat and foods harboring mature oocysts. In this study, we assessed the prevalence of T. gondii in sheep and goats coming from central Iran. After completing the questionnaire, about one gram of liver or diaphragm tissue was taken as a sample from 90 sheep and 90 goats slaughtered in Yazd Province and stored at $-20^{\circ} \mathrm{C}$. DNA extraction was done, and then T. gondii was detected using nested PCR.

Results: This study indicated that the prevalence of T. gondii in all slaughtered animals was $11.6 \%$ (21 of 180), including 14.4\% (13/90) in sheep and 8.8\% (8/90) in goats. The infection rates in liver and diaphragm samples were 12.2\% $(11 / 90)$ and $11.1 \%(10 / 90)$, respectively $(p=0.8163)$. The infection rate in animals older than one was $16.3 \%(15 / 92)$, and it was $6.8 \%(6 / 88)$ in animals under one year of age. Therefore, no significant differences were found $(p=0.475)$. Infection rates were $19.5 \%(18 / 92)$ in males and $3.4 \%(3 / 88)$ in females $(p=0.0007)$. In conclusion, the infection rates of toxoplasmosis in livestock in this area are almost high, and therefore, it is necessary to design appropriate prevention programs to control the disease.
\end{abstract}

Keywords: Toxoplasmosis, Foodborne disease, Nested PCR, Toxoplasma gondii

\section{Introduction}

Toxoplasmosis, as a widespread zoonotic disease worldwide, is caused by Toxoplasma gondii [1]. This protozoan belongs to the phylum Apicomplexa, which infects at least one-third of the human population [2]. T. gondii has a wide range of host species [3]. Besides, toxoplasmosis is considered the third disease globally, resulting in human hospitalization due to foodborne infection. In Iran, the mean seroprevalence rate of toxoplasmosis is $39.3 \%$ in the human population [4].

T. gondii life cycle includes three infectious stages; oocyst harboring sporozoite, shedding from the cats, and felids' feces as the definitive host, tachyzoite an active form in toxoplasmosis, tissue cyst inside the muscle

\footnotetext{
*Correspondence: eslami_g2000@yahoo.com

${ }^{4}$ Department of Parasitology and Mycology, School of Medicine, Shahid

Sadoughi University of Medical Sciences, Yazd, Iran

Full list of author information is available at the end of the article
}

and central nervous system [3]. This foodborne parasite may infect humans by consuming food and water contaminated by mature oocyst or eating rare or semi-rare cooked meat, or products with tissue cysts.

Meat coming from domestic animals harboring $T$. gondii is considered an important infection source in humans [5]. Pregnant women and anemic patients show interest in consuming raw meat and its products, liver, and other organs as they believe in their health benefits.

The prevalence of $T$. gondii in sheep and goats in different areas is between 24.5 and $33.3 \%$ [6-8]. Overall, the prevalence of toxoplasmosis is reported in the range of $28.5-78 \%$ among ovine worldwide $[9,10]$.

T. gondii is detected using fluorescent microscopy, serology tests, and molecular-based methods. The fluorescent microscopy is accurate, but it needs the live parasite. Besides, the serology tests are sensitive, but they yield false-negative results in some cases. Consequently, molecular-based techniques are considered the most

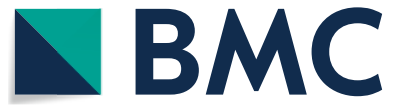

(c) The Author(s) 2021. This article is licensed under a Creative Commons Attribution 4.0 International License, which permits use, sharing, adaptation, distribution and reproduction in any medium or format, as long as you give appropriate credit to the original author(s) and the source, provide a link to the Creative Commons licence, and indicate if changes were made. The images or other third party material in this article are included in the article's Creative Commons licence, unless indicated otherwise in a credit line to the material. If material is not included in the article's Creative Commons licence and your intended use is not permitted by statutory regulation or exceeds the permitted use, you will need to obtain permission directly from the copyright holder. To view a copy of this licence, visit http://creativeco mmons.org/licenses/by/4.0/. The Creative Commons Public Domain Dedication waiver (http://creativecommons.org/publicdomain/ zero/1.0/) applies to the data made available in this article, unless otherwise stated in a credit line to the data. 
sensitive and specific methods [5] and were chosen as accurate and suitable methods for detecting this disease.

T. gondii was identified in goats and sheep using the PCR-based method, which may help assess the consumer's infection risk. Hence, in the present study, the prevalence of $T$. gondii in sheep's and goats' meat slaughtered in the slaughterhouse of central Iran was evaluated using the PCR-based method. Based on our knowledge, this is the first report of molecular detection of T. gondii in goats and sheep tissue using the nested-PCR assay in Central Iran.

\section{Main text \\ Methods}

\section{Area description}

The samples were obtained from the slaughterhouses in Yazd, the Yazd Province capital, located in central Iran. Its climate is dry and hot, with an average annual rainfall of $60 \mathrm{~mm}$, and an average humidity percentage of $31.5 \%$. Yazd is placed at $1203 \mathrm{~m}$ above sea-level and covers $16,000 \mathrm{~km}^{2}$.

\section{Sampling}

The samples were collected from the slaughterhouses of Yazd city. For this purpose, one g of the liver or diaphragm tissue of 90 slaughtered goats and 90 slaughtered sheep was taken as the sample. All samples were stored at $-20^{\circ} \mathrm{C}$ until the next step. Data such as age, gender, and location were recorded in the questionnaire.

\section{DNA extraction}

The salting-out method was used based on the protocol introduced in previous studies to extract genomic DNA $[11,12]$ with some modifications. Briefly, about $30 \mathrm{mg}$ of the sample was used for DNA extraction. NET buffer (Tris-HCl, pH 7.6, 50 mM; EDTA, pH 8, $25 \mathrm{mM}$; NaCl, $50 \mathrm{mM}$ ) was used for complete lysis of the tissue. About $900 \mu \mathrm{l}$ NET buffer plus $10 \mu \mathrm{l}$ proteinase $\mathrm{K}(20 \mathrm{mg} / \mathrm{ml})$ were added to each tube. After the vortex, each tube was incubated at $56{ }^{\circ} \mathrm{C}$ overnight. After centrifugation, the supernatant was transferred to a new sterile $1.5 \mathrm{ml}$ tube. For purification, $300 \mu \mathrm{l}$ saturated $\mathrm{NaCl}$ was added and mixed for $30 \mathrm{~s}$. Centrifugation was done for $10 \mathrm{~min}$ at $10,000 \mathrm{rpm}$, and then the supernatant was transferred to a new sterile $1.5 \mathrm{ml}$ tube. For DNA precipitation, two volumes of cold ethanol were added to each sample. After vortex, each sample was stored at $-20{ }^{\circ} \mathrm{C}$ for at least $30 \mathrm{~min}$. The centrifugation was done at $15,000 \mathrm{rpm}$ for $10 \mathrm{~min}$, and the supernatant was removed entirely. Afterward, the washing step was done with $70 \%$ cold ethanol. It should be mentioned that the extracted genomic DNA was soluble in TE buffer (Tris- $\mathrm{HCl}, \mathrm{pH} 7.6,10 \mathrm{mM}$; EDTA, pH 8, $1 \mathrm{mM}$ ). For quality and quantity evaluation of the extracted DNA, the agarose gel electrophoresis (0.8\%; Akhtarian, Tehran, Iran) and spectrophotometer (NanoDrop; Thermo Scientific, USA) were used, respectively. The extracted DNA was stored at $-20{ }^{\circ} \mathrm{C}$ for the next experiments.

\section{Nested PCR}

To detect $T$. gondii, the nested PCR was performed using the specific primer pairs B1: $5^{\prime}$-GGAACTGCATCCGTT CATGAG-3' $3^{\prime}$ and B2: $5^{\prime}$-TCTTTAAAGCGTTCGTGG TC-3' for the first step and B3: 5'-TGCATAGGTTGC AGTCACTG-3' and B4: 5'-GGCGACCAATCTGCG AATACACC $-3^{\prime}$ for the second round [13]. Amplification reaction for the first round was performed in a volume of $20 \mu$ l containing $1 \times$ master mix PCR (Ampliqon, Odense, Denmark), $0.5 \mu \mathrm{M}$ each primer (Pishgam, Tehran, Iran), and 100 ng extracted DNA. The second round' amplification reaction was the same as the first round, but $1 \mu \mathrm{l} \mathrm{PCR}$ product as the template. The amplification program for both rounds was $94{ }^{\circ} \mathrm{C}$ for $5 \mathrm{~min}$ as the first denaturation, then followed by 35 cycles of denaturation at $94{ }^{\circ} \mathrm{C}$ for $1 \mathrm{~min}$, annealing at $55{ }^{\circ} \mathrm{C}$ for $1 \mathrm{~min}$, elongation at $72{ }^{\circ} \mathrm{C}$ for $1 \mathrm{~min}$. The final extension was done at $72{ }^{\circ} \mathrm{C}$ for $5 \mathrm{~min}$. The amplification analysis was done using 3\% agarose gel electrophoresis. The fragment size of 94 bp in length showed T. gondii. For all rounds, positive and negative controls were used. The standard strain of T. gondii was purchased from Pasteur Institute, Tehran, Iran. The $\mathrm{dd}_{2} \mathrm{O}$ was used for negative control.

\section{Statistical analysis}

Statistical analysis was performed using SPSS version 16.0 , and the $\chi^{2}$ test was used to analyze the relationship between each variable, including sex, age, and parasite position with the toxoplasmosis infection. The significance level was considered as $p<0.05$.

\section{Results}

The nested PCR showed an amplicon of 94 bp in length in 21 samples (Fig. 1). Therefore, the prevalence of $T$. gondii in all slaughtered animals was $11.6 \%$ (21 of 180), including $14.4 \%$ (13 of 90 ) in sheep and $8.8 \%$ (8 of 90) in goats. The infection rate by $T$. gondii in liver and diaphragm samples were $12.2 \%$ (11 of 90 ) and $11.1 \%$ (10 of 90), respectively, which is not significant $(p=0.8163$; Table 1). The analysis revealed that $16.3 \%$ (15 of 92) of the infected slaughtered animals were more than one year old, and $6.8 \%$ (6 of 88 ) were under one year of age. There were no significant differences between infection rate and age $(p=0.475$; Table 1$)$. The sex analysis showed that $19.5 \%$ (18 of 92) of males and 3.4\% (3 of 88) of females were infected with T. gondii ( $p=0.0007$; Table 1$)$. 


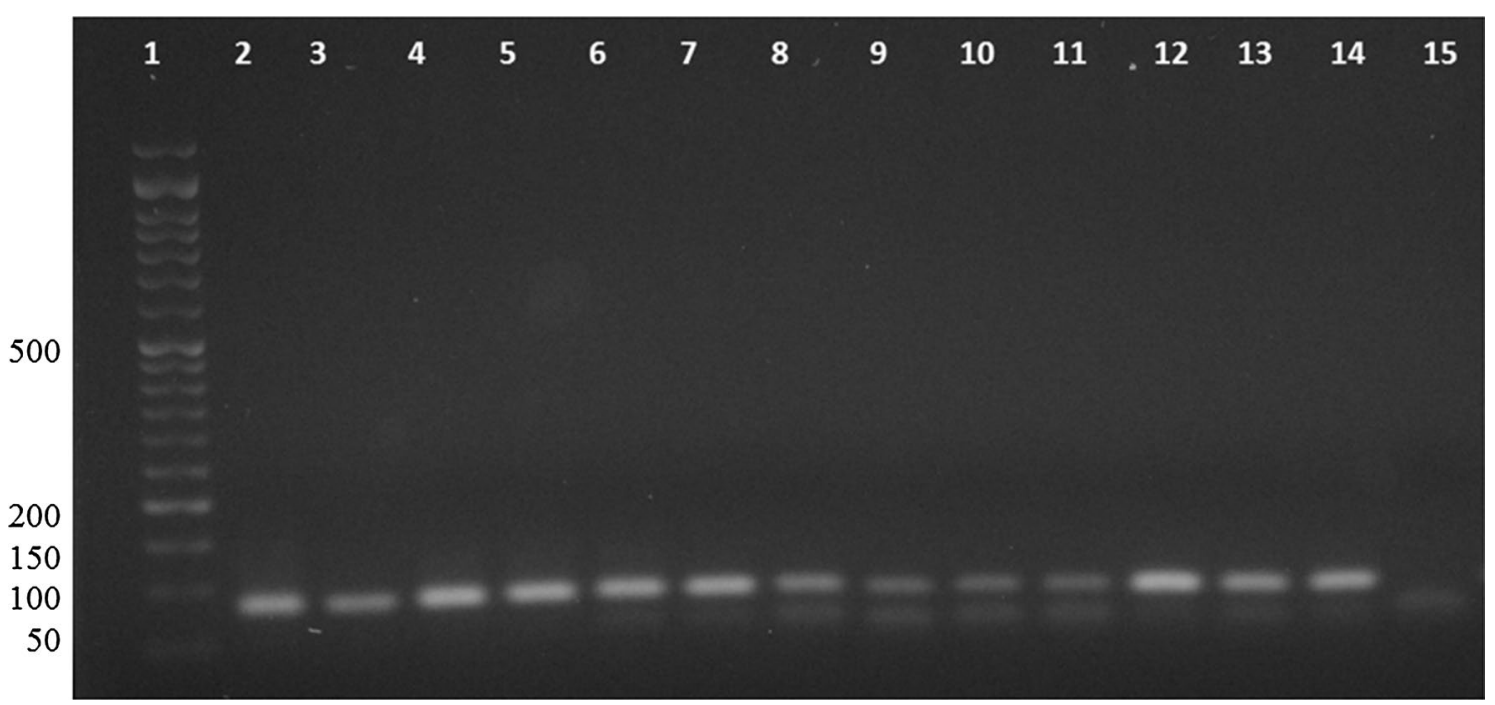

Fig. 1 Agarose gel electrophoresis for analysis of nested PCR for Toxoplasma gondii identification. The amplicon size 94 bp in length denotes T. gondii. Lane 1: 50 bp DNA ladder; lane 2: positive control (standard T. gondii from Pasteur Institute, Tehran, Iran); Ianes 3-14: the samples with T. gondii; lane 15: negative control $\left(\mathrm{ddH}_{2} \mathrm{O}\right)$

Table 1 The relationship between infection with Toxoplasma gondii and kind of animals, sex, age, and tissue type

\begin{tabular}{|c|c|c|c|c|c|c|c|c|c|c|c|c|}
\hline & \multicolumn{3}{|l|}{ Animal } & \multicolumn{3}{|l|}{ Sex } & \multicolumn{3}{|l|}{ Age } & \multicolumn{3}{|l|}{ Tissue } \\
\hline & Sheep & Goats & $p$ value & Male & Female & $p$ value & $>1$ & $<1$ & $p$ value & Liver & Diaphragm & $p$ value \\
\hline & No. (\%) & No. (\%) & & No. (\%) & No. (\%) & & No. (\%) & No. (\%) & & No. (\%) & No. (\%) & \\
\hline T. gondii & $13(14.4)$ & $8(8.9)$ & 0.25 & $18(20.4)$ & $3(3.2)$ & 0.0007 & $15(16.3)$ & $6(6.8)$ & 0.475 & $11(12.2)$ & $10(11.1)$ & 0.8163 \\
\hline Total & $21(11.7)$ & & & $21(11.7)$ & & & $21(11.7)$ & & & $21(11.7)$ & & \\
\hline
\end{tabular}

\section{Discussion}

Meat is one of the most important sources of animal protein in the human diet. However, it may be infected or contaminated by various types of pathogens, including bacteria, prions, fungi, and parasites, which may infect human consumers and lead to hazardous health problems. The parasitic infection in livestock has unsuitable effects on the meat industry's quality and threatens human health [13]. Several studies showed the prevalence of $T$. gondii in different kinds of meat [14-19]. In this regard, Boughattas et al. [20] studied the prevalence of T. gondii in humans who consumed sheep meat in Tunis using serological and PCR methods. Using the serological method, they showed that $38.2 \%$ of young sheep and $73.6 \%$ of the adult ones are infected, and using the PCR-based method, they found out that $50 \%$ of the samples from sheep tissues are HIV-positive [20]. Gebremedhin et al. [21] studied the prevalence of $T$. gondii infection in sheep and goats slaughtered in Ethiopia using the direct agglutination test (DAT), in which the prevalence of the parasite was reported $17.68 \%(111 / 628)$. They showed that the risk of infection with $T$. gondii in younger sheep is significantly higher than in adult ones, and the infection was higher during the wet seasons [21]. Our study results also indicated infection in adult sheep and the lambs, but there was no significant difference between infection rate and age. Khezri et al. [22] assessed the prevalence rate of $T$. gondii in sheep in different Kurdistan regions using a serological test, such as indirect ELISA. They reported that out of 368 sheep, $21.74 \%$ are serologically positive, among which $20.87 \%$ were male, and $22.13 \%$ were female sheep. Their analysis showed no significant difference between the sex and the rate of infection. However, we found a significant difference between age and the infection rate. Asgari et al. [23] identified the prevalence rate of infection in the edible tissues of the brain, tongue, liver, neck, ribs, and femur from 56 sheep and 22 goats in Shiraz using the PCR with an infection rate of $37.5 \%(21 / 56)$ and $22.7 \%(5 / 22)$, respectively. The overall prevalence of infection in animals was estimated to be $33.3 \%$. This infection rate was almost the same as the infection rate in our study. The rate of infection in females and males was $46 \%$ (9 of 14) and $29.5 \%$ 
(12 of 45), respectively, which is significantly different $(p=0.013)$. This study showed a significantly higher infection rate in males. One possible cause of this significant difference would be the difference in female care locations to provide milk. Therefore, the risk of contamination with oocysts expelled from cats will be decreased. Asgari et al. [23] also showed that the highest infected tissue in an orderly manner is the tongue (21.8\%), brain $(20.19 \%)$, and femoral intercostal muscles $(9.17 \%)$. In the current study, there was no significant difference between location and the infection. The findings showed that $12.2 \%$ of infection is in the liver; however, the consumption of rare or semi-rare sheep liver is traditionally common in the studied area. Thus, it is necessary to inform pregnant women and immunecompromised people to be careful while consuming rare or semi-rare sheep offal and liver. Seemingly, the essential way to prevent infection is educating people at higher risk about the life cycle of this parasite, informing people about consuming raw or undercooked meat, liver, and offal, preserving the meat either at $-20{ }^{\circ} \mathrm{C}$ for $24 \mathrm{~h}$ or at $-4{ }^{\circ} \mathrm{C}$ for $48 \mathrm{~h}$ before consumption, and cooking meat and its products at $70^{\circ} \mathrm{C}$.

\section{Limitation}

This study investigated the presence of $T$. gondii in goats' and sheep's meat. It is essential to design a program to prevent this infection in the region. This study's limitation was the small sample population used to analyze the accurate relationship between the infection rate and age, sex, and livestock parasite position.

\section{Abbreviations}

T. gondii: Toxoplasma gondii; PCR: Polymerase Chain Reaction; NET: NaCl, EDTA, Tris- $\mathrm{HCl}$.

\section{Acknowledgements}

We sincerely thank Mrs. Saeedeh Sadat Hosseini, and the technical supports of the Research Center of Food Hygiene and Safety, School of Public Health, Shahid Sadoughi University of Medical Sciences Yazd, Iran.

\section{Authors' contributions}

MB collected the samples, did the experiments, and wrote the manuscript's draft; BH designed the study, supervised the project, and analyzed the statistical analysis; GE designed the protocol and revised the manuscript's draft. All authors read the manuscript, revised and accepted it.

\section{Authors' information}

MB has MSC in Food Hygiene and Safety; BH is the head of the Department of Food Hygiene and Safety, Shahid Sadoughi University of Medical Sciences, Yazd, Iran; and GE is the head of the Parasitology and Mycology Department and the editor-in-chief of the Journal of Food Quality and Hazards Control at Shahid Sadoughi University of Medical Sciences, Yazd, Iran.

\section{Funding}

This research was supported by Shahid Sadoughi University of Medical Sciences, Yazd, Iran. None of the roles of design of the study, collection, analysis, interpretation of data, and writing the manuscript were done by Shahid Sadoughi University of Medical Sciences, Yazd, Iran.

\section{Availability of data and materials}

The datasets used and/or analyzed during the current study available from the corresponding author on reasonable request.

\section{Ethics approval and consent to participate}

All experiments and sampling procedures were performed following standard protocols approved by the Ethics Committee of Shahid Sadoughi University of Medical Sciences, Yazd, Iran.

\section{Consent for publication}

Not applicable.

\section{Competing interests}

The authors declare that they have no competing interests.

\section{Author details}

${ }^{1}$ Research Center for Food Hygiene and Safety, School of Public Health, Shahid Sadoughi University of Medical Sciences, Yazd, Iran. ${ }^{2}$ International Campus, Department of Food Hygiene and Safety, School of Public Health Shahid Sadoughi University of Medical Sciences, Yazd, Iran. ${ }^{3}$ Department of Food Hygiene and Safety, School of Public Health, Shahid Sadoughi University of Medical Sciences, Yazd, Iran. ${ }^{4}$ Department of Parasitology and Mycology, School of Medicine, Shahid Sadoughi University of Medical Sciences, Yazd, Iran.

Received: 14 August 2020 Accepted: 28 January 2021 Published online: 04 February 2021

\section{References}

1. Tenter AM, Heckeroth AR, Weiss LM. Toxoplasma gondii: from animals to humans. Int J Parasitol. 2000;30:1217-58. https://doi.org/10.1016/S0020 -7519(00)00124-7.

2. World Organisation for Animal Health-OIE. Terrestrial manual: toxoplasmosis [online]. Paris: OIE; 2017 [cited 2018 Aug 2].

3. Dubey JP, Jones JL. Toxoplasma gondii infection in humans and animals in the United States. Int J Parasitol. 2008;38:1257-78. https://doi. org/10.1016/j.jpara.2008.03.007.

4. Daryani A, Sarvi S, Aarabi M, Mizani A, Ahmadpour E, Shokri A, et al. Seroprevalence of Toxoplasma gondii in the Iranian general population: a systematic review and meta-analysis. Acta Trop. 2014;137:185-94. https:// doi.org/10.1016/j.actatropica.2014.05.015.

5. Robert-Gangneux F, Dardé M-L. Epidemiology of and diagnostic strategies for toxoplasmosis. Clin Microbiol Rev. 2012;25:264-96.

6. Hashemi-Fesharki R. Seroprevalence of Toxoplasma gondii in cattle, sheep and goats in Iran. Iran J Parasitol. 2011;6:90-4.

7. Sharif M, Sarvi S, Shokri A, Hosseini Teshnizi S, Rahimi MT, Mizani A. Toxoplasma gondii infection among sheep and goats in Iran: a systematic review and meta-analysis. Parasitol Res. 2015;114:1-16.

8. Khamesipour F, Doosti A, Iranpour MH, Komba EVG. Toxoplasma gondii in cattle, camels and sheep in Isfahan and Chaharmahal va Bakhtiary Provinces, Iran. Jundishapur J Microbiol. 2014;7:e17460.

9. Mancianti F, Nardoni S, D'Ascenzi C, Pedonese F, Mugnaini L, Franco F, et al. Seroprevalence, detection of DNA in blood and milk, and genotyping of Toxoplasma gondii in a goat population in Italy. Bio Med Res Int. 2013:2013:1-6l.

10. Cenci-Goga BT, Ciampelli A, Sechi P, Veronesi F, Moretta I, Cambiotti V, et al. Seroprevalence and risk factors for Toxoplasma gondii in sheep in Grosseto district, Tuscany, Italy. BMC Vet Res. 2013;9:25.

11. Hajimohammadi B, Dehghani A, Moghadam Ahmadi M, Eslami G, Oryan A, Khamesipour A. Prevalence and species identification of Sarcocystis in raw hamburgers distributed in Yazd, Iran using PCR-RFLP. J Food Qual Hazards Control. 2014;1:15-20.

12. Hajimohammadi B, Eslami G, Oryan A, Zohourtabar A, Pourmirzaei Tafti $H$, Moghaddam AM. Molecular identification of Sarcocystis hominis in native cattle of central Iran: a case report. Trop Biomed. 2014;31:183-6. 
13. lqbal A, Janecko N, Pollari F, Dixon B. Prevalence and molecular characterization of Toxoplasma gondii DNA in retail fresh meats in Canada. Food Waterborne Parasitol. 2018;13:e00031. https://doi.org/10.1016/j.fawpa r.2018.e00031.

14. Boughattas S, Bouratbine A. Genetic characterization of Toxoplasma gondii isolated from chicken meats in Tunisia. J Food Qual Hazards Control. 2015;2:97-100.

15. Boughattas S, Bouratbine A. Prevalence of foodborne Toxoplasma gondii in free-ranging chickens sold in Tunis, Tunisia. J Food Qual Hazards Control. 2014;1:89-92.

16. Sroka J, Bilska-Zając E, Wójcik-Fatla A, Zając V, Dutkiewicz J, Karamon J, et al. Detection and molecular characteristics of Toxoplasma gondii DNA in retail raw meat products in Poland. Foodborne Pathog Dis. 2019;16:195-204. https://doi.org/10.1089/fpd.2018.2537.

17. Plaza J, Dámek F, Villena I, Innes EA, Katzer F, Hamilton CM. Detection of Toxoplasma gondii in retail meat samples in Scotland. Food Waterborne Parasitol. 2020;20:e00086. https://doi.org/10.1016/j.fawpar.2020.e00086.

18. Sroka J, Karamon J, Wójcik-Fatla A, Piotrowska W, Dutkiewicz J, BilskaZając E, et al. Toxoplasma gondii infection in slaughtered pigs and cattle in Poland: seroprevalence, molecular detection and characterization of parasites in meat. Parasit Vectors. 2020;13:223. https://doi.org/10.1186/ s13071-020-04106-1.
19. Ai K, Huang CQ, Guo JJ, Zając V, Dutkiewicz J, Karamon J, et al. Molecular detection of Toxoplasma gondii in the slaughter sheep and goats from Shandong Province, Eastern China. Vector Borne Zoonotic Dis. 2020;20:193-6. https://doi.org/10.1089/vbz.2019.2488.

20. Boughattas S, Ayari K, Sa T, Aoun K, Bouratbine A. Survey of the parasite Toxoplasma gondii in human consumed ovine meat in Tunis city. PLoS ONE. 2014;9:e85044.

21. Gebremedhin Endrias Z, Abdurahaman M, Hadush T, Tessema ST. Seroprevalence and risk factors of Toxoplasma gondii infection in sheep and goats slaughtered for human consumption in Central Ethiopia. BMC Res Notes. 2014;7:696.

22. Khezri M, Mohammadian B, Esmailnia K, Khezri O. Toxoplasmosis in sheep from Kurdistan province, Iran. Afr J Microbiol Res. 2012;6:3989-92.

23. Asgari Q, Sarnevesht J, Kalantari M, Adnani Sadat SJ, Motazedian $\mathrm{MH}$, Sarkari B. Molecular survey of Toxoplasma infection in sheep and goat from Fars province, Southern Iran. Trop Anim Health Prod. 2011:43:389-92.

\section{Publisher's Note}

Springer Nature remains neutral with regard to jurisdictional claims in published maps and institutional affiliations.
Ready to submit your research? Choose BMC and benefit from:

- fast, convenient online submission

- thorough peer review by experienced researchers in your field

- rapid publication on acceptance

- support for research data, including large and complex data types

- gold Open Access which fosters wider collaboration and increased citations

- maximum visibility for your research: over $100 \mathrm{M}$ website views per year

At BMC, research is always in progress.

Learn more biomedcentral.com/submissions 